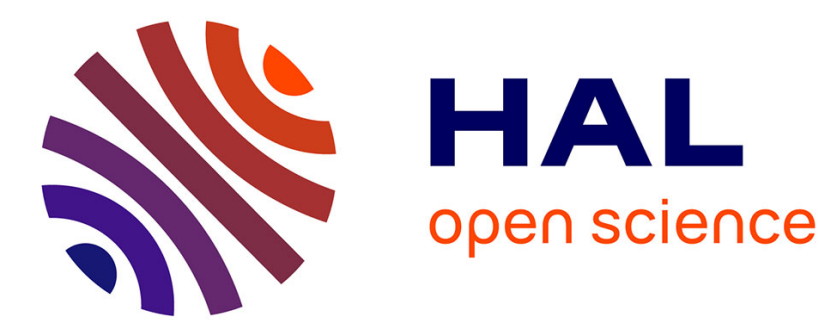

\title{
The role of technology in collaborative consumer communities
}

\author{
Samuel Guillemot, Hélène Privat
}

\section{To cite this version:}

Samuel Guillemot, Hélène Privat. The role of technology in collaborative consumer communities. Journal of Services Marketing, 2019, 33 (7), pp.837-850. 10.1108/JSM-12-2018-0361 . hal-02466593

\section{HAL Id: hal-02466593 \\ https://hal.univ-brest.fr/hal-02466593}

Submitted on 7 Apr 2021

HAL is a multi-disciplinary open access archive for the deposit and dissemination of scientific research documents, whether they are published or not. The documents may come from teaching and research institutions in France or abroad, or from public or private research centers.
L'archive ouverte pluridisciplinaire HAL, est destinée au dépôt et à la diffusion de documents scientifiques de niveau recherche, publiés ou non, émanant des établissements d'enseignement et de recherche français ou étrangers, des laboratoires publics ou privés. 


\title{
The role of technology in collaborative consumer communities
}

\author{
Samuel GUILLEMOT, Univ Brest, LEGO, Quimper, France \\ Hélène PRIVAT, Univ Bretagne Sud, LEGO, Lorient, France
}

Purpose - While some collaborative consumption activities are underpinned by commercial logics and dispositions, local collaborative consumer communities are organised around non-commercial values and driven by the desire to organise social relationships differently. These communities are based on the notions of a commons, sharing and reciprocity. However, because they make little use of digital tools (internet to coordinate the exchange of services, social media to communicate), they are not very visible to consumers. This research proposes to identify these non-commercial organisations' relationship to digital tools and to determine how these organisations can generate individual and/or collective well-being.

Design/methodology/approach - This study examined the case of the Local Exchange Trading System (LETS), a local collaborative consumer community that practices a moneyless exchange of services. A qualitative study was conducted based on 23 in-depth interviews with LETS managers.

Findings - Due to the communities' local roots and regular face-to-face meet-ups, there did not seem to be a pressing need to use an online platform to coordinate the exchange of services. However, the results showed that the use of digital tools increased these communities' well-being potential (e.g. development of social ties, solidarity, social equality) while reducing their negative effects (e.g. fatigue due to community involvement, difficulty integrating new members). They also introduce the notions of generation, founder's personality and management team's dynamism into the collaborative consumption literature.

Originality/value - It is important to focus on how these "alternative" markets function. Consumers use them but without abandoning more traditional markets. Understanding how they work improves our understanding of the competition they pose to traditional services and how the different ecosystems complement one another.

Keywords - Collaborative consumption - Collaborative consumer community - Digital tools - Local Exchange Trading System - Well-being - Non-commercial services

Paper type - Research paper

This research was founded by Région Bretagne (M@ rsouin).

TO CITE: GUILLEMOT, S. AND PRIVAT, H. (2019), THE ROLE OF TECHNOLOGY IN COLLABORATIVE CONSUMER COMMUNITIES, JOURNAL OF SERVICE MARKETING, 33 (7), 837-850

Digital technologies have led to the emergence of some high-profile platforms, which are regularly held up as working models, for the production and consumption of collaborative services (e.g. AirBnB, RideSharing, BlaBlaCar). There is a wealth of academic literature on the subject (i.e. Belk, 2014; Decrop et al., 2017; Ertz et al., 2016; Scaraboto, 2015) due to its theoretical (e.g. understanding new organisational and consumption structures) and managerial contributions (e.g. increasing and retaining a community of users, visibility, building trust, etc.). Interestingly, very little is known about local collaborative consumer communities, which are the original forms of these consumer networks. These organisations offer opportunities for individuals living in the same geographical area (neighbourhood, town, borough or county) to get in touch and exchange services between themselves. Generally, exchanges are moneyless, mediated by a scriptural "currency" based on the equivalence mechanism, in other words one hour given is equivalent to one hour received (Guillard, 2017). For example, one hour of DIY could be exchanged against one hour of guitar lessons. The exchanges are highly varied and can concern the home (e.g. shopping, walking the dog, decorating, gardening), transport (e.g. car sharing, bicycle maintenance), children (e.g. private tutoring, childcare), food (e.g. organic food, jams, recipes, food and health advice) or training (e.g. foreign language courses, piano lessons, cookery lessons). The movement first emerged in the 1990s, but the development of the internet and mobile apps has contributed to its rediscovery and evolution through various models combining the nature of the exchange, the type of exchange platform (physical or 
digital, managed by the members themselves), the nature of the commodity (services and/or knowledge, goods), the unit of account (local currency, time) and the nature of the membership (individuals, families and/or collectives).

The aim of this study was to gain a better understanding of the organisation of such communities. This involved integrating two areas of consumer literature. One was the literature on collaborative consumption. Ertz et al (2016) define collaborative consumption as "the set of resource circulation systems which enable consumers to both obtain and provide, temporarily or permanently, valuable resources or services through direct interaction with other consumers or through a mediator". Generally speaking, consumers navigate between these collaborative markets and the more traditional commercial markets (Herbert and Collin-Lachaud, 2017). A better understanding of how they work would give us a better understanding of the "competition" this sector poses to traditional services and of how ecosystems compete with and complement one another. The second area of consumer literature mobilised was that on Transformative Service Research (TSR). This literature postulates that services enable the transformation of individuals and organisations. This is important because the performance of service organisations can have positive outcomes, such as well-being, which is relevant at individual, collective and ecosystem levels (Anderson et al., 2013; Ostrom et al., 2010). For example, a collaborative consumer community offering an IT and internet literacy service to older adults will improve the situation not only of the individuals concerned (e.g. in terms of accessing services requiring the internet) but also of society as a whole (e.g. reducing the "digital divide" between generations).

The article is organised as follows. First, it sets out the theoretical framework that helped to define the research question. The literature highlighted the fact that the well-being potential of local collaborative consumer communities was proving difficult to achieve because these organisations made either very little or no use of digital tools (e.g. website to coordinate exchanges, social media to communicate), thus reducing their visibility and accessibility to consumers. The research question therefore aimed to clarify the relationship that these communities had with digital tools. What were the factors that explained this low-level use? And what were the consequences for the well-being of individuals, the community and society as a whole? This section is followed by a presentation of the research method, which comprised a series of 23 semi-structured interviews with members of these communities' management teams. The results are then presented and discussed. They show that because the communities were locally rooted and held regular face-to-face meet-ups with members, the use of digital tools was not crucial in terms of keeping them alive. However, they did prove very useful in maximising their well-being potential when they eliminated negative effects (e.g. fatigue due to long term commitment, membership renewal problems, attraction of the collaborative market economy, etc.) without diminishing positive effects (e.g. development of social ties, solidarity, social equality, etc.). The results also highlighted the role of generation and ideology as well as the founder's personality and the management team's dynamism into digital tools' adoption. The article concludes with a discussion of the theoretical and managerial contributions of this research.

\section{THEORETICAL BACKGROUND}

The aim of this section is to clarify the notion of collaborative consumer community. In order to demonstrate the relevance of the research question, the notion is examined within the framework first of the collaborative consumption literature and then of the TSR literature. 


\section{Collaborative consumer communities and collaborative consumption}

According Botsman and Rogers (2011), collaborative consumption associates lifestyle with modes of resource allocation and exchange beyond traditional market norms (e.g. goods can be shared or rented). Thus "collaborative lifestyles" refers to the organised exchange of services where individuals in need of a service (e.g. DIY, transport, cleaning, etc.) are put in contact with other individuals or companies. The aggregation of participants' efforts to achieve common or compatible goals is one of the key features of collaborative lifestyles (Scaraboto, 2015). However, as Figueiredo and Scaraboto (2016) highlighted, there is a difference between the concepts of collaborative consumer networks and collaborative consumer communities. These two concepts express different aspects of a consumer collective. "Collaborative consumer network" emphasises connectivity, while "collaborative consumer community" emphasises identity.

A collaborative consumer network refers to a group of consumers who are largely autonomous and often geographically distributed. These consumers are heterogeneous in terms of their setting, culture, social capital and goals (Figueiredo and Scaraboto, 2016). The rapid evolution of the internet is one of the key features of collaborative consumer networks (Scaraboto, 2015), with computer networks supporting consumers to collaborate in order to better achieve common or compatible goals and interactions. Traditional carpooling (BlaBlaCar, AmigoExpress), real-time carpooling (Uber) and accommodation-sharing (HomeAway, Couchsurfing) are well-known manifestations of this phenomenon. Originally presented as a revolutionary mode of consumption (Botsman and Rogers, 2011), research has shown that some consumers nevertheless take up these activities with commercial logics and dispositions (Guyader, 2018; Herbert and Collin-Lachaud, 2017).

A collaborative consumer community, on the other hand, emphasises "aspects linked to shared identity, shared consciousness, rituals and traditions, common social practices, a sense of belonging to an in-group, and a sense of obligation to the community and its members" (Figueiredo and Scaraboto, 2016). Collaborative consumer communities are driven by the desire to organise social relationships differently, which derives from the notions of a commons (Bardhi and Eckhardt, 2012; Eckhardt and Bardhi, 2016), sharing (Belk, 2010, 2011) and reciprocity ("mutuality", Arnould and Rose, 2016). The marketing literature sheds light on communities organized around brands (Muniz and O'Guinn, 2001) or subcultures of consumption (Schouten and McAlexander, 1995). When the community is organized around the exchange of services, the local area is totally appropriate (Boutet-Diéye, 2015). With the aim to construct and maintain social ties, such organisations can be seen as a potential alternative to market norms (Bauwens and Lievens, 2015; Coriat, 2015; Moulier-Boutang, 2010). Due to the communities' local roots, they make little or no use of digital tools (BoutetDiéye, 2015). This remains an obstacle in terms of their development. Projects that have no internet presence are not very visible, which does not facilitate their uptake, even within their own local ecosystem (Boutet-Diéye, 2015).

In summary, Table 1 recaps the main differences between the collaborative consumer community and the more frequently studied collaborative consumer network. It's important to note that the bounds of those constructs could be contrasted. For example, there could be a national community with active local subchapters (e.g. Rotary), or there could be a local community that uses digital tools a lot (e.g. Nextdoor.com or Care.com). Thus, there are grey areas in-between and these two "archetypes" are the ends of the spectrum. 
Table 1. Differences between the two types of collaborative lifestyle systems

\begin{tabular}{|c|c|c|}
\hline & $\begin{array}{c}\text { Collaborative consumer } \\
\text { network archetype }\end{array}$ & $\begin{array}{l}\text { Collaborative consumer } \\
\text { community archetype }\end{array}$ \\
\hline Definition/Illustrations & $\begin{array}{l}\text { Community organised } \\
\text { around practices } \\
\text { e.g. carpooling, } \\
\text { couchsurfing }\end{array}$ & $\begin{array}{l}\text { Community organised } \\
\text { around a project or shared } \\
\text { values } \\
\text { e.g. Time Banking, Local } \\
\text { Exchange Trade System }\end{array}$ \\
\hline Geographical area & Distributed & $\begin{array}{l}\text { Mainly localised (e.g. } \\
\text { neighbourhood, town, } \\
\text { borough, county) }\end{array}$ \\
\hline Involvement of members & Low involvement & High involvement \\
\hline Commercial orientation & Market oriented & Alternative to market norms \\
\hline Use of IT & High-level use & Low-level use \\
\hline
\end{tabular}

\section{Collaborative consumer communities and Transformative Service Research}

The literature on collaborative consumer communities emphasises the well-being outcomes of such organisations. The marketing literature in this domain sheds light on time banking (Ozanne and Ozanne, 2016), ecovillages (Kozinets and Belz, 2011), associations supporting small-scale farming (Dufeu and Ferrandi, 2013), structures connecting people who want to declutter with those looking for second-hand items (Freecycle, Arsel and Dobscha, 2011) and Local Exchange Trading Systems (LETS) (Privat, 2014). These kinds of organisations have been established to build cohesive communities. The benefits of collaborative community membership are both economic and psycho-social and include a better quality of life and opportunities for using skills (Birch and Liesch, 1997). First, collaborative consumer communities generate a local dynamic through an exchange network (Guillard, 2017). Second, they reduce the local community's reliance on external goods and services, so the community becomes more self-sufficient and its wealth remains within the community (Birch and Liesch, 1997; Laamanen et al, 2015; Ozanne et Ozanne, 2011). Third, these communities provide greater social equity by offering people without paid employment the opportunity of casual work (Guillard, 2017). As such, the TSR framework is pertinent because it promotes research on ways in which organisations can fulfil their well-being potential. TSR postulates that services have the power to transform individuals, organisations and societies. The interaction between service entities (e.g. service employees, service processes or offerings, organisations or service sectors) and consumer entities (e.g., individuals, collectives, the ecosystem) affects the well-being outcomes of both (Anderson et al., 2013).

\section{Research question}

As already mentioned, local collaborative consumer communities, unlike the collaborative consumer networks more frequently discussed in the literature, make little use of digital tools (internet, social media). While it could be suggested that these communities, by their very nature (local-level actions, high-level member involvement, etc.), do not need these tools, a review of the literature indicates that they have the potential to create well-being at the 
individual, collective and ecosystem levels. However, their low-level use of digital tools represents a barrier to fulfilling this well-being potential because it means they only have lowlevel visibility and accessibility. The research question therefore aims to provide an understanding of these collaborative consumer communities' use of digital tools. More specifically, the study will answer three questions: What use do the communities make of digital tools? What are the factors that explain this use? And what are the consequences of this in terms of well-being outcomes?

In order to guarantee homogeneity of results, the research focused on one specific form of local collaborative consumer community, namely the LETS (Local Exchange Trading System). A LETS is a non-profit association whose members live in the same geographical area. These members barter and exchange services without exchanging money using a local currency that is linked to time invested.

\section{METHOD}

A qualitative semi-structured interview method was used. This method was selected because it was well suited to responding to the study's general aim of understanding these communities' relationship with digital tools. This section presents the interviewees' characteristics and the data analysis method used (Meyrick, 2006).

\section{Sample}

In order to ensure that the results were representative, data were collected over an entire geographical territory. The geographical unit chosen was the région, a French administrative district, because LETS are primarily communities that develop at local level. The région chosen was Brittany, France. Brittany is a geographical and cultural entity. It is situated in the western tip of France on a peninsula, located between two seas, the English Channel and the Atlantic Ocean. While the central area of the region is rural and sparsely populated, Brittany has two metropolises at its extremities as well as several medium-sized, interconnected towns. This geographical configuration offers a variety of different LETS (rural, suburban, urban).

French LETS are all members of an association that is responsible for promoting and developing them. This association listed 31 LETS for the territory studied. All 31 were contacted with an invitation to participate in the study. Seventeen agreed. When the remaining 14 were contacted at a later date (after the interviews had been conducted with the first 17), 6 further associations also agreed to participate in the study. The 8 LETS that had declined to participate were no longer active. The final corpus therefore consisted of 23 LETS covering a delimited geographical territory. With an average age of 9 years, these communities were fairly young. The youngest had been founded 1 year before the study was conducted, and the oldest 25 years before, corresponding to the arrival of this organisational structure on French territory. The average number of members was 56, although this fluctuated between 15 and 150 (appendix). It is interesting to note that community size correlated with community age.

\section{In-depth interviews and data analysis}

Because LETS are non-profit community organisations, initiated at the local community level and democratically organised and managed, they operate on a collegial, voluntary basis and are managed by a team of 3 to 5 people. The convention is that someone decides to create a community (the founder) and gathers a team around them to help them in that task. This team 
is responsible for organising the community and promoting it in order to recruit new members. One person from each of the LETS management teams was systematically interviewed (13 women and 10 men, including 9 founders). The management team was chosen for interview because it had a global view of the organisation's functioning and a good knowledge of its membership. It should be noted that while the individuals in the management teams also offered and consumed services as community members, they spoke here on behalf of the organisation. A semi-structured interview schedule was developed around three major themes, namely the history of the community's development, the community's organisational and management skills (with a focus on IT) and the community's ideology. The interviews were conducted over the telephone and lasted on average 45 minutes (appendix). They were then recorded and transcribed.

A thematic analysis of the data was carried out (Huberman and Miles, 1991). First, the verbatim accounts were coded according to themes indicating their content. A bottom-up method was then applied to the themes, in other words themes sharing a common notion were grouped into the more general categories that gradually emerged. The coding process used the existing theoretical background and was supplemented with emergent concepts. To improve the validity of the results, double coding was carried out by the authors. Finally, the two authors discussed the themes and examined their relationship to the consumption of services.

\section{FINDINGS}

The results of the analyses are presented in Figure 1. They confirm that the use of digital tools was limited in the LETS studied. This can be explained in part by their philosophy that the face-to-face encounter should be at the heart of the organisation's life. This result was moderated to varying degrees by the personal characteristics of the LETS members, including their generation and anti-consumption ideology, and by the founder's personality and the management team's dynamism. The use of digital tools nevertheless appeared decisive in terms of the LETS' ability to fulfil their well-being potential because it prevented negative consequences such as membership fatigue (burnout, sense of obligation), lack of accessibility and difficulty integrating into the local ecosystem. 


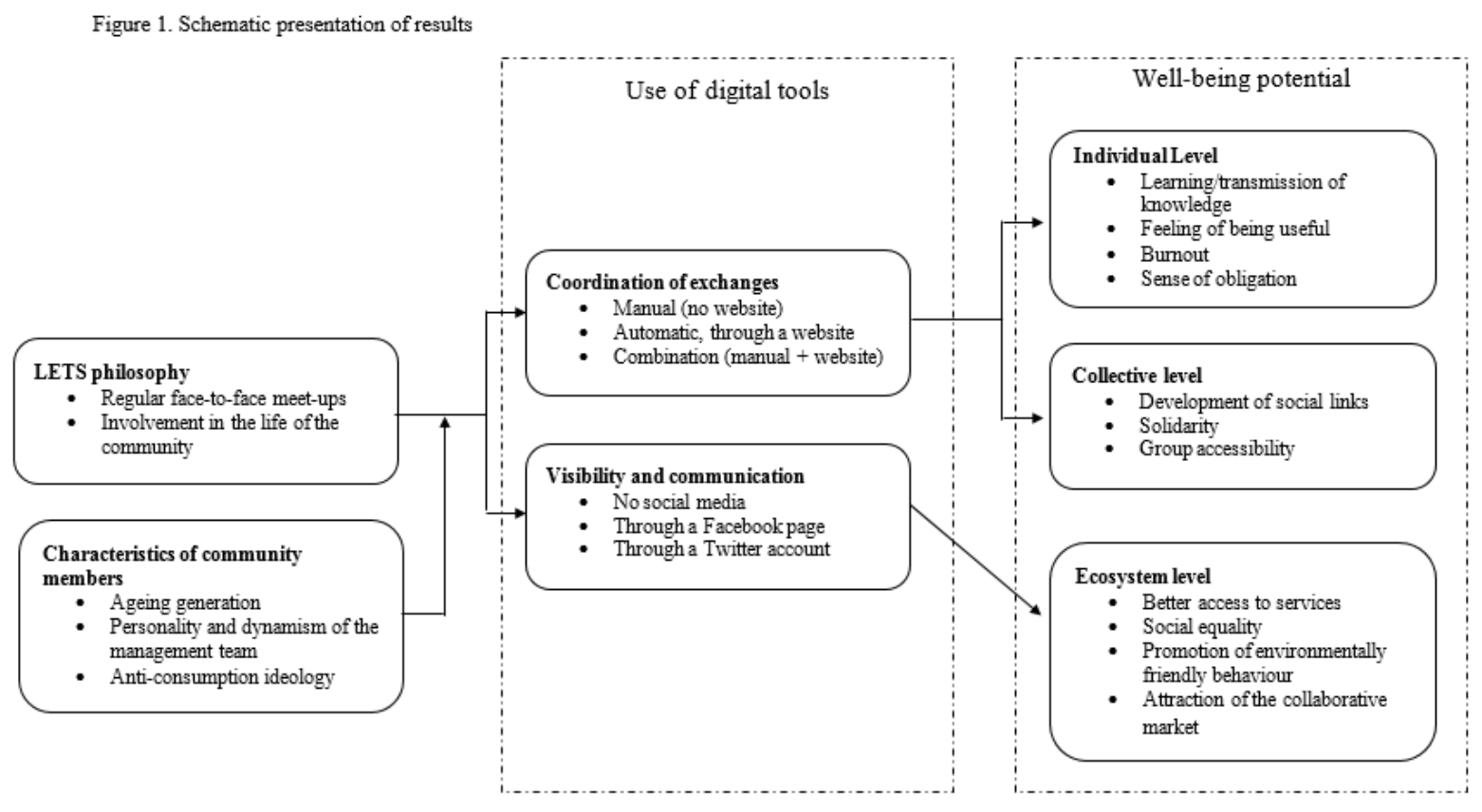

\section{Use of digital tools}

An analysis of the interviews revealed that digital tools were used in two ways: a website for coordinating exchanges and social media for integration into the local ecosystem. Table 2 shows that just less than half of the LETS used a website to coordinate their exchanges, and just over a quarter communicated through social media.

Table 2. Use of digital tools

\begin{tabular}{lrr}
\hline & $\mathrm{N}$ & \multicolumn{1}{c}{$\%$} \\
\hline Internet site & & \\
Does not use digital tools (stage 0) & $47.39 \%$ \\
Has only a business card website (stage 1) & 6 & $26.09 \%$ \\
Has a website that facilitates the coordination of exchanges & 11 & $47.82 \%$ \\
$\quad$ Coexistence of traditional coordination method (using printed catalogue) (stage 2) & 3 & $13.04 \%$ \\
$\quad$ No coexistence of traditional coordination method (stage 3) & 8 & $34.78 \%$ \\
Has a website that tracks exchanges (stage 4) & 2 & $8.70 \%$ \\
\hline Social media & & \\
Does not use social media & 17 & $73.91 \%$ \\
Has a Facebook page & 6 & $26.09 \%$ \\
Has a Twitter account & 2 & $8.70 \%$ \\
\hline
\end{tabular}

As far as internet use was concerned, 5 stages of digital development were identified. "Stage 0 " referred to those LETS whose use of digital tools was limited to sending and reading emails. In these cases, a member of the management team was responsible for centralising service offers and requests, aggregating them into a file and distributing them, either in paper or digital format (by email), or both. "Stage 1" referred to those LETS whose digital development extended to a business card website (i.e. a website providing practical information such as address, phone number, etc.). These websites were rather outdated and had often been created using first-generation templates from Web 2.0. They were mainly used to provide information 
on the LETS philosophy to non-members. "Stage 2" referred to LETS that used an intranet site to automatically coordinate exchanges "in real time". This website was a "turnkey" website offered to each LETS by the association responsible for promoting their development. Each member had their own personal space on this site where they could enter their service offers or requests, which were then automatically distributed to the whole community.: "You post an ad and it's out there. As soon as someone's got a new ad, an event, everyone gets it by email as well. Even those who don't go to the website, there's a mailing list to all members and everyone gets the info. I think it's really good for sharing information. It's working well anyway" [LETS 07]. Of the 13 LETS in this category, some maintained both systems (i.e. exchanges were coordinated through both the intranet and a printed catalogue) (stage 2) while others had moved to a fully digitally coordinated system (stage 3). The transition period can be explained by the time required to adopt the new tool: "At least we do have a website, but for now we still need to keep the printed catalogue. The website's not really taken off yet. The majority of members still haven't used it. We've got someone in the management team who's in charge of centralising the ads from the website and those that come in by email in a printed catalogue" [LETS 03]. As well as connecting up members so that they could use the service, a LETS's mission was to record exchanges to ensure that the members acted as both offerers and requesters. The traditional way of doing this was as follows. Each member had a logbook in which they recorded all services rendered and consumed. Both parties had to sign this logbook whenever an exchange took place. The logbooks were sent to the management team once a year, where they were reviewed and balanced. At the time of data collection, despite the fact this option was available on the intranet site offered to the LETS, only 2 LETS had dematerialised this process via the website (stage 4).

The use of online social networks was much less widespread within the LETS. Only 6 had a social media presence (Facebook). The Facebook page (when it was used) communicated information about events organised by the LETS and relayed information on local news or matters of interest and on other associations with similar values. Of these 6 LETS, 2 also had a Twitter account, but these were not used (one with 3 and one with 4 followers). There was no link between the use of social media and the coordination of exchanges using the intranet because 4 of the 6 LETS that used Facebook did not use the intranet to coordinate exchanges.

\section{Factors explaining the use of digital technology}

This section explores why the LETS had (totally or partially) or had not adopted digital tools. The reasons found were associated with the LETS "face-to-face" philosophy and/or with the characteristics of the individuals who made up the community.

The LETS philosophy. A LETS's activities was not just confined to the exchange of services. An essential component of a LETS was regular face-to-face meet-ups. The objective was to create social connections: "The exchange is really just a pretext. We use them to create links with people. For example, people get me to do DIY, I fix plugs. I'll do the job and then we'll have a coffee and a chat. Links are created during the exchange, and they're maintained through the monthly meetings and the meals afterwards" [LETS 16]. Moreover, a face-to-face meet-up was a prerequisite for integration into the community, eliminating those who did not join for the right reasons: "So an example would be "I'm going to join the LETS to get my bathroom done up", but that's not how it works. [...] A LETS is simply about giving people a helping hand, it's not about 'we're going to build a house', it's never going to be about doing big projects. It's all about keeping it simple" [LETS3]. However, while these face-to-face meet-ups were a feature of the LETS, some were more active in organising them than others. As with the different stages of digital development identified, there was also a gradation found in the number of activities organised by the communities. All the LETS offered a monthly meeting that usually concluded with a meal (level 1). The more active LETS also organised thematic 
workshops for the exchange of knowledge and know-how (level 2). For example, different members would lead cooking workshops (e.g. LETS 11), craft workshops (e.g. LETS 12) or training on a specific computer software (e.g. LETS 20). The most active LETS offered further opportunities for their members to meet up (level 3), including get-togethers (e.g. tea parties, meals, hikes; e.g. LETS 01), exchange meetings organised around a particular theme (e.g. garden, flowers) and sometimes side projects (e.g. community vegetable garden, craft workshops; e.g. LETS 13).

A comparison of the LETS' activity levels with their stages of digital development (Table 3 ) reveals that the majority of active LETS used the intranet to coordinate their exchanges (43\% of LETS). One of the explanations they put forward for this was that the time saved through automatically coordinating exchanges was reinvested in organising activities: "The internet's a great tool. It saves us a lot of time when it comes to organising the community. It's more or less automatic so we can concentrate on other things [...] But you've got to be careful, it's a useful tool, but it's got to respect the whole raison d'être of the LETS, it okay as long as it doesn't replace face-to-face meet-ups" [LETS 02]. A proliferation of opportunities for members to meet face-to-face created a virtuous circle within the community that stimulated service offers and requests. These connections allowed members to identify needs and offers of service during discussions: "People call on each other for stuff, when they know one another, even for things that have nothing to do with their initial adverts. Like, sometimes, when we're chatting in the bar on Wednesdays, someone will say 'actually, I have such-and-such a problem' and someone else will say 'I can solve your problem. I can help you'. Whereas, at the start, neither of them had voiced this need or said they might have this skill" [LETS 01]. These social bonds partly explain why the use of digital social networks is perceived by many to be superfluous: "we are a social network, that's the thing. There are Facebook-style social networks and there are LETS-style social networks. [...] And for me, these are real social networks, I mean, they're real people, we meet real people, we have real friends." [LETS 02].

Table 3. Level of activity compared with stage of digital development

\begin{tabular}{|c|c|c|}
\hline & $\begin{array}{l}\text { Non-digital LETS (digital } \\
\text { development stage } 0 \text { or } 1 \text { ) }\end{array}$ & $\begin{array}{c}\text { Digital LETS } \\
\text { (digital development stage } 3 \\
\text { or } 4 \text { ) }\end{array}$ \\
\hline $\begin{array}{l}\text { Inactive LETS } \\
\text { (activity level 1) }\end{array}$ & $\begin{array}{c}22 \% \text { of LETS } \\
(\text { LETS } 4,5,8,17,21)\end{array}$ & $\begin{array}{l}\text { 13\% of LETS } \\
\text { (LETS } 14,15,19)\end{array}$ \\
\hline $\begin{array}{c}\text { Active LETS } \\
\text { (activity level } 2 \text { or } 3 \text { ) }\end{array}$ & $\begin{array}{c}22 \% \text { of LETS } \\
\text { (LETS } 6,10,12,13,18)\end{array}$ & $\begin{array}{c}43 \% \text { of LETS } \\
\text { (LETS } 1,2,3,7,9,11,16,20 \text {, } \\
22,22)\end{array}$ \\
\hline
\end{tabular}

However, while some of the very active LETS were found not to be digitally developed (22\%), some of the very inactive LETS had a higher than average stage of digital development $(13 \%)$. This was due to a moderating effect created by the community members' characteristics.

Characteristics of individual community members. The higher levels of digital tool use could be explained by several factors directly associated with the community members. Table 4 illustrates these themes with quotes from the data and indicates the number of LETS that they applied to. 
Table 4. Characteristics of individual community members

\begin{tabular}{lll}
\hline Theme & $\mathrm{N}$ & Illustrations \\
\hline Generation & 14 & "Like 90\% of LETS, it's a group of people on the verge of retirement \\
or already retired. [...] LETS don't attract young people, or very, \\
very rarely. That's just the way it is." [LETS 04] \\
"We're old! We're the baby boomer generation. It's all about the \\
internet now, the problem is we old ones don't have much to do with \\
the internet." [LETS 13] \\
"We're in the category of slightly older people who're not very \\
comfortable with computers. The most they'll do is read their emails \\
[...]. These people just tend to read emails, the newspaper, the \\
municipal newsletter, stuff like that." [LETS 5]
\end{tabular}

The founder's "the person who founded it had a strong personality, he was very

personality and the management team's dynamism
$(43.83 \%)$ unifying. When he left, we just drifted along really, for a long time." [LETS 7]

"Our LETS has a reputation locally for being dynamic. By that I mean we have a lot of workshops, a lot of people participating, a lot of exchanges. [...] we eat together, a lot of people turn up [...] it's really lively. Some LETS are much more "fuddy-duddy", let's just say our management team is quite young. So, I don't know, maybe that's part of it actually. In the management team, we agreed that we'd always try to offer at least 4, 5, 6 workshops, and in fact when we come into the management team, that's exactly what we try to do." [LETS 02]

"we're a young team. We're all mums with children in school. That's how we recruit, when we go to pick up the kids, so that inevitably has an influence, we don't necessarily attract the same kind of people as, say, the older LETS." [LETS 23]

\begin{tabular}{lc}
\hline Members' & 7 \\
ideology & $(30.43 \%)$
\end{tabular}

\footnotetext{
"People who join the LETS are, well some of them anyway, either very critical or very disillusioned. Actually, some more than others. Either they're really really against today's society, or they're not so against it [...]. For them Facebook is a product of Capitalism, it's one of the reason why the world going mad [...] We can't, ethically speaking, we can't institutionalise [Facebook] because it doesn't fit with our values." [LETS 02]

"Our ethos that there is no division. Everyone is useful no matter what they bring. And if we start posting our digital histories and all that, it's going to create divisions. The aim is to bring people together, to unite as much as possible, not to divide." [LETS 10]
}

The first factor that might explain the low-level use of the internet and social media was the community members' generation. The majority of the LETS were aging, mainly attracting retirees. There were two main reasons for this. On the one hand, members needed to have enough free time to devote to the many meetings, something that young parents and 9-5 workers do not necessarily have. On the other, the LETS were not visible to the younger generations, who mainly get their information from the internet or social media. The LETS managers recognised that the lack of digital communication posed a problem of visibility (especially among the younger generations): "all LETS have this problem. Generations under the age of 30 don't necessarily understand the value of LETS because they already use AirBnB, etc. They don't see the difference" [LETS 13]; "anyway, if we want to reach the 20-25 age group, we'll need to use the same communication channels as they do. We're debating whether to use Facebook, but Facebook is already out-of-date for the young ones!"' [LETS 23]. 
The second factor was the community founder's personality, which appeared to be a key element in a community's organisation. The founder tended to bring together a management team that was similar to themselves. For example, a young founder would attract a young team, a militant founder would attract a militant team, and so on. They were the ones who decided whether or not to introduce the website for coordinating exchanges and who could galvanise the community through their organisational approach. Those founders who had introduced the internet despite generation-related reluctance had employed various tactics, including having intranet exchanges written in the statutes (LETS 14), automatically registering new members on the website (LETS 22), providing support for inputting entries on the website during monthly meetings (LETS 01) and offering training in the form of workshops (LETS 20) or video tutorials as well as instructions for use (LETS 23).

The third factor was ideological in nature. A LETS is a group of people who advocate a new, non-money-based society. These people therefore reject the "consumer society". Facebook and social media in general are perceived as being products of this society. They are perceived as two sides of the same coin. As such, these tools are rejected as a matter of principle. Although the managers were aware that their LETS's lack of visibility was causing it to age and that it would ultimately lead to its disappearance altogether, the adoption (or not) of digital communication was a source of tension within the management teams. Many clashes had been recorded following the adoption of social media for communication, ranging from the departure of some members to the splitting of some communities in two: "The use of Facebook was the subject of quite a heated discussion within the management team. The person who managed the first website even left the LETS because of it!" [LETS 01].

\section{Impact on well-being potential}

The interviews confirmed the findings of previous studies, namely that local collaborative consumer communities have a high well-being potential at individual (e.g. learning and/or passing on of skills, feeling of being useful), collective (e.g. creation of social links and solidarity between community members) and ecosystem levels (e.g. better access to services, equality, promotion of environmentally sustainable behaviour). Nevertheless, the contribution of this study is that it shows that this well-being potential is fragile and that it is threatened by negative consequences. One of the advantages of digital tools is that they can prevent, or at least mitigate, these negative effects. Table 5 illustrates the well-being outcome statements (positive and negative and on different levels) accompanied by the frequency with which the themes appeared and quotes to illustrate. The text bellow summarises these outcomes and with additional quotes links them to the use of digital technology. These points are illustrated by looking at well-being from the individual, collective and ecosystem perspectives.

Table 5. The LETS' well-being outcomes

\begin{tabular}{lcl}
\hline & $\%$ & Illustrations \\
\hline Individual level & & \\
\hline Positive outcomes & & \\
\hline $\begin{array}{l}\text { Learning/Passing on } \\
\text { of skills }\end{array}$ & 6 & $\begin{array}{l}\text { "We teach foreign languages and skills like sewing and crafts. } \\
\text { There's no limit. People's desire to pass on knowledge generates } \\
\text { the desire to learn in others" [LETS 01] }\end{array}$ \\
\hline $\begin{array}{l}\text { Feeling of being } \\
\text { useful }\end{array}$ & $\begin{array}{l}6 \\
\text { "Knowing that you can help is important for some people. It's good to } \\
\text { feel useful again. Especially when you're retired" [LETS 09] }\end{array}$ \\
\hline
\end{tabular}

\section{Negative outcomes}




\begin{tabular}{ccc}
\hline Burnout & 10 & $\begin{array}{l}\text { "I've tried using the website to communicate. It's time-consuming. I } \\
\text { tried to find volunteers to help me with it. The problem is we don't have } \\
\text { enough volunteers... you get tired of it and demotivated" [LETS 14] }\end{array}$
\end{tabular}

\begin{tabular}{ccc}
\hline Sense of obligation & 5 & $\begin{array}{l}\text { "you feel that sense of obligation that sometimes exists in families [...] } \\
\text { which is a burden, when you feel you have to go say hello to your } \\
\text { grandmother or eat lunch once a week at your parents" or whatever" } \\
\text { [LETS 04] }\end{array}$
\end{tabular}

\begin{tabular}{lcl}
\hline Collective level & \\
\hline Positive outcomes & & "We also get families with children, single people, people who've \\
\hline Development of & $(78.26 \%)$ & $\begin{array}{l}\text { never been to a LETS before and then find themselves retired or } \\
\text { social links } \\
\text { widowed and decide to join to create new social ties. And I believe } \\
\text { that's one of the LETS's biggest objectives, beyond its fairly } \\
\text { alternative economic objective, I believe its objective is also to rebuild } \\
\text { social ties, especially in rural areas, to connect people who wouldn't } \\
\text { have connected in other ways." [LETS 02] }\end{array}$
\end{tabular}

\begin{tabular}{|c|c|c|}
\hline Solidarity & $\begin{array}{c}12 \\
(52.17 \%)\end{array}$ & $\begin{array}{l}\text { "Beyond the recorded exchanges and all that, there's a whole other } \\
\text { thing going on, 'well, at the moment, so-and-so's not well, so-and- } \\
\text { so's got some health problems, she's put up an ad for someone to } \\
\text { clean her house'. We know she's not very well, we're going to look } \\
\text { out even more for someone who's put up an ad for someone to clean } \\
\text { her house aren't we, because we know she's not well, we know } \\
\text { she's having health problems at the moment." [LETS 14] }\end{array}$ \\
\hline
\end{tabular}

\begin{tabular}{|c|c|c|}
\hline Negative outcomes & & \\
\hline $\begin{array}{l}\text { Group accessibility } \\
\text { and service } \\
\text { accessibility }\end{array}$ & $\begin{array}{c}7 \\
(30.43 \%)\end{array}$ & $\begin{array}{l}\text { I think our numbers are just going to dwindle until [the LETS] } \\
\text { fizzles out altogether [...]. Because people, the longer it goes on, } \\
\text { the harder it is for people to come in, new people, because the } \\
\text { group becomes more and more established as the months and years } \\
\text { go on, and that makes it difficult for people from the outside to } \\
\text { come in, even if we all make a big effort to welcome them [...] } \\
\text { Joining a group is complicated enough already, but here, it's... we } \\
\text { certainly don't have the answers anyway for making it easier for } \\
\text { people to integrate. [LETS 08] }\end{array}$ \\
\hline
\end{tabular}

\begin{tabular}{lcl}
\hline Ecosystem level & & \\
\hline Positive outcomes & & \\
\hline Better access to & 4 & "we have welcomed migrants. It means they can access services they \\
services & $(17.39 \%)$ & $\begin{array}{l}\text { wouldn't be able to get normally or which would be difficult for them } \\
\text { to access" [LETS 12] }\end{array}$
\end{tabular}

Social equality

3 "There's a little egalitarian side to the LETS [...]. Someone who does

(13.04\%) one hour of sewing is equal to the technician who comes to fix your computer for an hour or the person who comes to dig over your garden for an hour. At the end of the day, it's actually quite the opposite of the real world because someone who sweeps a yard and someone who has studied to be an engineer, they wouldn't be paid the same salary, but in the LETS they are paid the same salary." [LETS 10]

\begin{tabular}{lcl}
\hline $\begin{array}{l}\text { Promotion of } \\
\text { environmentally }\end{array}$ & 7 & "There are a lot of people who believe in doing things themselves. At \\
friendly behaviour & $(30.43 \%)$ & $\begin{array}{l}\text { the LETS, we repair our clothes, we don't buy new clothes when } \\
\text { they've got holes in them. There's a culture of recycling. [...] So } \\
\text { there's a culture of not buying, throwing out, consuming."[LETS 13] }\end{array}$
\end{tabular}

\begin{tabular}{lcc}
\hline Negative outcomes & & \\
\hline $\begin{array}{l}\text { Attraction of the } \\
\text { collaborative market }\end{array}$ & $(17.39 \%)$ & "Idon't know. Imust admit sometimes I'm... well, not worried exactly, \\
\hline
\end{tabular}


collaborative, commercial types of economics, in inverted commas, sometimes win out over this type of exchange, which is really focused fundamentally on the non-commercial, predominantly. [...] there are all these collaborative websites that give a second life to stuff, like Leboncoin [a French freeads website], [...]. There are a lot of these kinds of things popping up out there, for objects, which can sometimes be more popular than moneyless exchanges. " [LETS 09]

Well-being at individual level. While participation in a LETS allowed members to feel useful and learn new skills (Table 5), it could also have negative effects. For the management team, having to volunteer so much of their time could result in fatigue and burnout. In this sense, coordinating exchanges through a website helped to lighten the load in the LETS that had adopted the system: "It's amazing how much time I've saved since the offers and service requests have been made on the website. I still spend a bit of time supervising it, but a lot less than I used to. For example, sometimes people put up ads with requests in euros. I have to make sure no one's engaging in any professional activity. Basically, I have to make sure everything on there stays within the LETS spirit" [LETS 19]. A second negative effect highlighted by 5 of the LETS related to the constraints associated with the long-term commitment and the "obligation" to participate in the community's events. These "mandatory" meetings could become a constraint that members tired of over time. One of the respondents made an analogy with the binding aspect that can exist within families (Table 5). Again, the use of digital tools could help members better manage their participation in the various events: "Yes, there are a lot of meetings. But there's no point in arranging meet-ups if no one's interested or available. We use this great thing, it's an online survey thing. It's called Doodle. We'll suggest a meet-up, say, a hike. And people will say if they intend to participate. And we only organise it if there are enough yeses" [LETS 02].

Well-being at community level. Given the LETS' mission is to create social cohesion through the exchange of services, it was not surprising to find the themes of wider community wellbeing and solidarity running through the majority of the discourse (in $78.26 \%$ and $52.17 \%$ of the LETS, respectively). The establishment of a LETS within a neighbourhood or town resulted in a revitalisation of social ties. The way in which the community operated meant that everyone knew their neighbours and that they communicated and exchanged with them. This aim to create human contact between individuals living close to one another geographically could moreover be of benefit to isolated or vulnerable people (Table 5). Nevertheless, the stability of this modus operandi appeared to be precarious. There was a risk that the community might close in on itself and become inaccessible. As soon as people knew one another, as soon as friendships had been forged, the exchanges were no longer always formalised: "Actually, I noticed that transactions in the LETS often start by being very organised, recorded in the exchanges logbook and all that, and then, quite quickly, things become more human as well and then in the end, very often, in the end, the exchanges are not formalised at all any more. I don't know if you know what I mean? In other words, we move beyond that stage, friendships are made, connections are forged and so not everything is necessarily formalised in the sense that it's almost like an excuse, actually, to start something" [LETS 02]. However, it was thought that these non-formalised exchanges should not become the norm because they did not promote the integration of new members. The face-to-face element was also a barrier to new members joining because the affinities were strong and it is sometimes difficult to join a group that is already formed (Table 5). Recording exchanges was therefore vital for attracting and retaining new community members. Digital tools could be helpful in this respect: "Yes, it's obvious people should be encouraged to register their offers and requests for services on the website [...] Actually, it's always give and take. For example, I've heard people say, 'It's time I organised something because I won't have any points left soon'. At the end of the day, it's just like it is in the real world, if we want goods or services, we have to give something otherwise we'd be in debit all the time. So, it works, people have really taken it on board actually. [LETS 02]. 
Well-being at ecosystem level. The positive aspects of LETS have already been demonstrated, namely access to services for those most in need, social equality and the promotion of environmentally sustainable behaviour (Table 5). These positive aspects can also have a real impact at societal level if the LETS is integrated into the local ecosystem because its values can circulate and spread. Of the 23 LETS surveyed, 10 reported no or very few links either with other LETS or with other associations or public bodies. Their fear was that such a link would create some form of competition with other local associations (e.g. "we had a problem with a humanitarian association, which accused us of stepping on its toes!" [LETS 10]) or the defection of their members to commercial trading sites. Indeed, some managers were even frightened at the prospect of competition from other forms of collaborative consumption (Table 5). It seemed that the most "closed" LETS promoted just one single value, most often anti-consumerism. A number of the 13 who had forged links with other associations or public bodies used social media to connect to the local ecosystem: "I use the association's Facebook page to advertise our events but also mainly to pass on information about other associations with similar values to us, on the social and solidarity economy, on the environment" [LETS 16]. Others had even developed partnerships (organising joint events, passing on news, etc.). Some communities were very active and wanted to open up further, even if it meant going beyond the scope of their LETS: "The philosophy is to create a link with the town, so that the benefits remain localised but they benefit the greatest number of people. If we limit ourselves to the LETS moneyless approach, we won't be able to reach a wider audience. We've got to think about the non-commercial - the gift, the barter - but also the commercial if we want to be part of the social and solidarity economy [...] We've started discussions with other associations in the town. The municipality has recognised the initiative, and we're now in the planning phase to develop an application based on a local currency" [LET 23]. Digital tools were a useful means of coordinating this type of project, which would see the LETS' own currency transformed into a local currency used by local associations and businesses (LETS 11, 18 and 23).

\section{DISCUSSION}

The general aim of this article was to gain a better understanding of local collaborative consumer communities. These communities have significant development potential because they are part of the movement towards a sustainable economy. By examining the role of technology in these organisations in relation to their well-being potential, this research has provided insights on two questions (What is the role of technology in providing service efficiency and effectiveness? And what is the relationship between service sustainability, profitability and well-being?) that were identified as research priorities by the Journal of Services Marketing (Russell-Bennett and Rosenbaum, 2019).

\section{Theoretical contributions}

This research provides a better understanding of local collaborative consumer communities' relationship to services. Consumers have a number of expectations when they enter into an exchange-of-services process. These expectations are focused on the result (benefit from the service) and/or the process, that is on what is happening in human terms during the exchange (Guillard, 2017). In the case of the LETS studied here, it was the process that was important. The service was just a pretext - a prop - for the social relationship (Cova, 1997). While this profile is also found in collaborative consumer networks (e.g. the "communal collaborative consumption" found by Guyader (2008) in his study on carsharing, where the participants sought pro-social relationships from their community membership), it was predominant here. However, is it possible to say that the consumers were completely detached from any commercial logic? The notion of giving is primordial in a LETS. It could even be said to be its driving force, with a donation/counter-donation logic that becomes unequivocal (Le Gall-Ely, 
2014). Because the exchanges are logged, consuming a service (receiving a donation) implies that a service has to be offered in turn (making a donation). However, the fact that this unit of account (time or virtual currency) exists at all shows that not all individuals are totally detached from commercial logics. Moreover, this unit of account seemed essential in terms of integrating new consumers and "connecting" with the world.

Another contribution of this study is that it introduces the notion of generation into the collaborative consumption literature. It is an accepted fact that the rapid evolution of digital technologies has led to the further development of already existing collaborative practices. However, older users' use of technology does not evolve as quickly as that of younger users. Hence, while the LETS were wondering whether it might be a good idea to use a website to coordinate their exchanges and Facebook to communicate, the younger generations had already moved on to other tools, such as mobile apps and other social media, to communicate. Although the LETS were places for learning and for passing on skills and knowledge, it seems that consumer practice (i.e. the consumer habitus) was not being passed on. In addition to the digital gap, one of the explanations for this is that the transmissions were mainly between the 80-yearolds generation and the 50-year-olds generation, which had both already shaped and embedded their consumer habits. When collaborative consumer communities include children, the convivial relationships create a psychosocial environment that is conducive to the transmission of consumer habits (Guillemot, 2018). For example, in a study of associations supporting smallscale farming, Beaudoin (2018) noted that parents often came to do their shopping with their children and used these trips to discuss with their children the importance of buying locally.

A third contribution of this study is that it focuses attention on the ideology and values of the members of collaborative organisations. An examination of locally-based ideologically marked organisations reveals that their integration into the ecosystem depends largely on the founder's personality and the management team's dynamism. They are the standard bearers of a generation and of the values on which the community is based. This pull effect is particularly strong when the community is local and actual (as opposed to virtual). For example, some communities are very marked by "anti-consumption" and as a result are less well integrated into the local ecosystem than those promoting broader values such as the environment and the social and solidarity economy.

Finally, the results of this study confirm that collaborative consumer communities have significant potential to create well-being not just at individual level but also at organisational and societal levels. However, this study shows that the balance of well-being is precarious and that a LETS can also generate negative affects (lack of well-being). For example, tensions, fears and even a form of fatigue and burnout were recorded at organisational level, while a sense of obligation and pressure to offer new services were recorded at individual level. These negative affects corresponded with a significant level of involvement in the LETS community. Nevertheless, it seems that the adoption of digital tools, which could only be achieved if this fitted with the LETS philosophy, offered a way of preventing these negative effects.

\section{Managerial implications}

The results of this research make it possible to formulate a number of managerial recommendations. The digital transition is the biggest challenge facing local collaborative consumer communities. Their refusal to make the transition is often linked to an unfamiliarity with digital tools. In the case of LETS, this leads to a fear that the face-to-face element that differentiates this type of community from other forms of collaborative consumption will disappear. This differentiated positioning must be highlighted, and digital communication should not be seen as incompatible with this. Current managers should therefore be offered 
training. The communities in this study that had successfully made their digital transition were those that had incorporated young people into their management teams and/or which had been founded by people accustomed to using digital tools. While the introduction of digital tools will come about with generational renewal, this will take place only gradually and will be dependent on the second challenge that faces these communities, namely the integration of new members. The coordination of exchanges via the internet seems once again to offer an interesting solution since it allows new members to see offers and to offer their services on a "neutral" medium. As such, they have the same level of information as longstanding members. Tallying the exchanges through the website is also important. In this sense, the existence of a framework with rules seems essential in order to clarify everyone's roles, avoid profiteers and create a balance between supply and demand. This framework also acts as a means of preventing the entry of undesirable members (Hofmann et al., 2017) who would not respect the community's values.

Finally, the development of local collaborative communities is complex because the number of exchanges and the renewal of skills, knowledge and know-how is difficult in a human-sized community. One solution would be to strengthen links and increase exchanges between different communities. This could be possible if everyone coordinated their exchanges via a shared website. In addition to an increase in possible exchanges, this would give this type of community visibility. However, care should be taken not to stray into an "over-management" situation (King, 2017). These digital tools must serve the non-commercial organisation without creating additional bureaucracy and pressure and without distorting its core values.

\section{Limitations and avenues for future investigation}

The first limitation was that only the team managers' perspective was taken into account. A study of the whole community would complement the managers' comments. Second, it would have been interesting to have surveyed the eight defunct organisations in order to find out why they are defunct. In addition, a replication of this study in other regions and cultures and in other local collaborative community structures (e.g. ecovillages, associations supporting smallscale farming, etc.) would increase its external validity. Finally, it would be interesting to extend this study by directly interviewing the users in order to more accurately identify consumer "tactics" and the links that exist between traditional commercial communities, collaborative network communities and local collaborative communities. In order to promote the well-being potential, especially at societal level, it would also be interesting to follow consumers as they move from one community to another and to see which elements facilitate or hinder this transition.

\section{BIBLIOGRAPHY}

Anderson, L., Ostrom, A.L., Corus, C., Fisk R.P., Gallan A.S., Giraldo, M., Mende, M., Mulder, M., Rayburn, S.W., Rosenbaum, M.S., Shirahada, K. and Williams, J.D (2013), "Transformative service research: An agenda for the future", Journal of Business Research, Vol.66 No.8, pp.1203-1210.

Arnould, E.J. and Rose, A.S. (2016), "Mutuality: Critique and substitute for Belk's 'sharing"” Marketing Theory, Vol.16 No.1, pp.75-99.

Bardhi, F. and Eckhardt, G.M. (2012), "Access-based consumption: The case of car sharing", Journal of Consumer Research, Vol.39 No.4, pp.881-898.

Bauwens, M. and Lievens, J. (2015), Sauver le monde: Vers une société post-capitaliste avec le peer-to-peer, Les liens qui libèrent, Paris. 
Beaudouin, V. (2018), “Analyse du pouvoir transformatif d'une forme de commercialisation alternative: le cas du dispositif Amapien", Actes des 17èmes journées normandes de recherche en consommation (JNRC), Université de Rouen Normandie (21-22 November)

Belk, R. (2010), "Sharing”, Journal of Consumer Research, Vol 36, No.5, pp.715-734.

Belk, R. (2011), "Le concept de don", in Bergadaà, M., Le Gall-Ely, M. and Urien, B. (eds), Don et pratiques caritatives, De Boeck, Brussels pp.19-33.

Belk, R. (2014), "You are what you can access: Sharing and collaborative consumption online", Journal of Business Research, Vol.67 No.8, pp. 1595-1600.

Birch, D. and Liesch, P. (1997), "Moneyless exchange: Attitudes of participants in Australian community barter systems", Journal of Nonprofit and Voluntary Sector Marketing, Vol.2, $\mathrm{N}^{\circ} 3$, pp.240-251.

Botsman, R. and Rogers R. (2011), What's Mine is Yours: How collaborative consumption is changing the world we live, Harper Colin, London, $2^{\text {nd }}$ edition.

Boutet-Diéye, A. (2015), "Consommation collaborative et numérique" in Briand, G. and Boutet-Diéye, A. (2015), Les conditions d'un développement du mouvement de la consommation collaborative en Bretagne, Bretagne Consommation Collaborative, pp.51-57.

Coriat, B. (2015), Le retour des communs: la crise de l'idéologie propriétaire, Les liens qui libèrent, Paris.

Cova, B. (1997), Community and consumption: Towards a definition of the "linking value" of product or services, European journal of marketing, Vol.31(3/4), pp. 297-316.

Decrop, A. (2017), La consommation collaborative: Enjeux et défis de la nouvelle société de partage, De Boeck Supérieur, Louvain-la-Neuve.

Dufeu, I. and Ferrandi, J-M. (2013), "Les ressorts de l'engagement dans une forme particulière d'échange collaboratif entre producteurs et consommateurs: les AMAP", Décisions Marketing, Vol.72, pp.157-178.

Eckhardt, G. and Bardhi, F. (2016), "The relationship between access practices and economic systems", Journal of the Association for Consumer Research, Vol.1 No.2, pp. 210-225.

Ertz, M., Durif, F. and Arcand, M. (2016), "Collaborative consumption: conceptual snapshot at a buzzword”, Journal of Entrepreneurship Education, Vol.19 No.2, pp.1-23.

Figueiredo, B. and Scaraboto, D. (2016), "The systemic creation of value through circulation in collaborative consumer networks", Journal of Consumer Research, Vol.43 No.4, pp.509533.

Guillard, V. (2017), "Comprendre la relation collaborative d'échange de temps au sein des Accorderies, Une analyse par la théorie de l'échange social", Revue Française de Gestion, $\mathrm{N}^{\circ} 265$, pp.9-24.

Guillemot, S. (2018), "Intergenerational transmission in consumer behaviour: An integrative conceptual framework and future research directions", Recherche et Applications en Marketing (English Edition), Vol.33 No.2, pp.93-114.

Guyader, H. (2018), "No one rides for free! Three styles of collaborative consumption", Journal of Services Marketing, Vol.32 No.6, pp.692-714.

Herbert, M. and Collin-Lachaud, I. (2017), "Collaborative practices and consumerist habitus: An analysis of the transformative mechanisms of collaborative consumption", Recherche and Application en Marketing (English Edition), Vol.32 No.1, pp.42-62.

Hofmann, E., Hartl, B. and Penz, E. (2017), "Power versus trust - what matters more in collaborative consumption?", Journal of Services Marketing, Vol. 31 No.6, pp.589-603.

Huberman, A. M. and Miles M. B. (1991), Analyse des données qualitatives - Recueil de nouvelles méthodes. Brussels: De Boeck Université

King, D. (2017), "Becoming Business-Like: Governing the Nonprofit Professional", Nonprofit and Voluntary Sector Quarterly, Vol.46 No.2, pp. 241-260. 
Kozinets, R. and Belz, F-M. (2011), "The indefinite future": Ideas, ideals, and idealized ideology in the global eco-village", in Advances in Consumer Research, Vol.39, pp. 65-68.

Laamanen, M., Wahlen, S. and Campana, M. (2015), "Mobilising collaborative lifestyles: A comparative frame analysis of time banking", International Journal of Consumer Studies, Vol 39, N5, pp. 459-467.

Le Gall-Ely, M. (2014), "Giving in consumer research and marketing: A state of the art", Recherche et Applications en Marketing (English Edition), Vol.28 No.4, pp.44-67.

Meyrick, J. (2006), "What is a good qualitative research? A first step towards a comprehensive approach to judging rigour/quality", Journal of Health Psychology, Vol.11 N5, pp.799-808

Moulier-Boutang, Y. (2010), L'abeille et l'économiste, Carnets Nord, Paris.

Muniz, A.M. and O'Guinn T.C. (2001), "Brand community", Journal of Consumer Research, Vol.27 N4, pp 412-432

Ostrom, A.L., Bitner, M.J., Brown, S.W., Burkhard, K.A., Goul, M., Smith-Daniels, V., Demirkan, H. and Rabinovich E. (2010), "Moving Forward and Making a Difference: Research Priorities for the Science of Service", Journal of Service Research, Vol.13 No.1, pp. 4-36.

Ozanne, L. and Ozanne, J.L. (2016), "How alternative consumer markets can build community resiliency", European Journal of Marketing, Vol.50 No.3/4, pp.1-27.

Privat, H. (2014), Etude des motivations au sélisme: dimensionnement, antécédents et influence sur la pratique séliste, $\mathrm{PhD}$ thesis, Université de Bretagne Occidentale, France.

Russell-Bennett, R. and Rosenbaum, M.S. (2019), "Editorial”, Journal of Services Marketing, Vol. 33 Issue: 1, pp.1-4

Scaraboto, D. (2015), "Selling, sharing, and everything in between: The hybrid economies of collaborative networks", Journal of Consumer Research, Vol.42 No.1, pp.152-176.

Schouten, J.W. and McAlexander, J.H (1995), "Subcultures of consumption: An ethnography of the new bikers, Journal of Consumer Research, Vol.22 Nº 1, pp43-61 


\section{APPENIDIX. Main characteristics of LETS surveyed}

\begin{tabular}{|c|c|c|c|c|c|c|c|c|}
\hline & $\begin{array}{l}\text { Respondent } \\
\text { characteristics }\end{array}$ & $\begin{array}{l}\text { Interview } \\
\text { duration } \\
\text { (mins) }\end{array}$ & $\begin{array}{l}\text { Age of the } \\
\text { LETS (in } \\
\text { years) }\end{array}$ & $\begin{array}{l}\text { Number of } \\
\text { members } \\
\text { (range in } \\
\text { brackets) }\end{array}$ & $\begin{array}{l}\text { LETS membership } \\
\text { profile }\end{array}$ & $\begin{array}{l}\text { Use of digital tools } \\
\text { (digital } \\
\text { development stage) }\end{array}$ & $\begin{array}{l}\text { Level of activity } \\
\text { (opportunities for face- } \\
\text { to-face meet-ups) }\end{array}$ & $\begin{array}{l}\text { Integration into } \\
\text { the local } \\
\text { ecosystem }\end{array}$ \\
\hline $\begin{array}{l}\text { LETS } 01 \\
\text { (urban) }\end{array}$ & $\begin{array}{l}\text { Female/ Member } \\
\text { of management } \\
\text { team (founder) }\end{array}$ & 35 & 6 & $60[45-80]$ & $\begin{array}{l}\text { Aged between } 30 \\
\text { and } 90 . \text { Majority } \\
\text { retired. } \\
\text { Socially diverse. }\end{array}$ & $\begin{array}{l}\text { Exchanges } \\
\text { coordinated using } \\
\text { the internet (stage } \\
\text { 3) } \\
+ \text { Facebook } \\
+ \text { Twitter }\end{array}$ & $\begin{array}{l}\text { Monthly meetings } \\
+ \text { Regular knowledge- } \\
\text { exchange workshops } \\
+ \text { Weekly meals/socials } \\
\text { in a bar }\end{array}$ & $\begin{array}{l}\text { Links with other } \\
\text { local associations } \\
\text { (information } \\
\text { passed on) }\end{array}$ \\
\hline $\begin{array}{l}\text { LETS } 02 \\
\text { (rural) }\end{array}$ & $\begin{array}{l}\text { Female/ Member } \\
\text { of management } \\
\text { team }\end{array}$ & 66 & 8 & $60[50-70]$ & $\begin{array}{l}\text { Aged between } 25 \\
\text { and } 80 \text { (average age } \\
+/-50) \text {. Female. }\end{array}$ & $\begin{array}{l}\text { Exchanges } \\
\text { coordinated using } \\
\text { the internet (stage } \\
\text { 3) }\end{array}$ & $\begin{array}{l}\text { Monthly meetings } \\
\text { + Regular knowledge- } \\
\text { exchange workshops } \\
\text { + Other occasional } \\
\text { events }\end{array}$ & $\begin{array}{l}\text { Links with other } \\
\text { local associations } \\
\text { (information } \\
\text { passed on) }\end{array}$ \\
\hline $\begin{array}{l}\text { LETS } 03 \\
\text { (rural) }\end{array}$ & $\begin{array}{l}\text { Female/ Member } \\
\text { of management } \\
\text { team }\end{array}$ & 37 & 25 & 90 [80-100] & $\begin{array}{l}\text { Aged between } 7 \\
\text { and } 80 \text { with the } \\
\text { majority aged } \\
\text { between } 50 \text { and } 60 .\end{array}$ & $\begin{array}{l}\text { Exchanges partly } \\
\text { coordinated using } \\
\text { the internet (stage } \\
\text { 2) }\end{array}$ & $\begin{array}{l}\text { Bimonthly meetings } \\
\text { + Occasional } \\
\text { knowledge-exchange } \\
\text { workshops }\end{array}$ & $\begin{array}{l}\text { Links with other } \\
\text { local associations } \\
\text { (information } \\
\text { passed on) }\end{array}$ \\
\hline $\begin{array}{l}\text { LETS } 04 \\
\text { (rural) }\end{array}$ & $\begin{array}{l}\text { Male/ Member of } \\
\text { management team } \\
\text { (founder) }\end{array}$ & 61 & 8 & 30 [20-40] & $\begin{array}{l}\text { Aged between } 40 \\
\text { and } 80 \text {. }\end{array}$ & $\begin{array}{l}\text { No website (stage } \\
0 \text { ) }\end{array}$ & Monthly meetings & $\begin{array}{l}\text { Links with other } \\
\text { local associations } \\
\text { (information } \\
\text { passed on) }\end{array}$ \\
\hline $\begin{array}{l}\text { LETS } 05 \\
\text { (urban) }\end{array}$ & $\begin{array}{l}\text { Female/ Member } \\
\text { of management } \\
\text { team (founder) }\end{array}$ & 31 & 3 & 15 [10-20] & $\begin{array}{l}\text { Aged between } 30 \\
\text { and } 81 \text { (average age } \\
+/-50) \text {. }\end{array}$ & $\begin{array}{l}\text { Business card } \\
\text { website (stage 1) } \\
+ \text { Facebook }\end{array}$ & Monthly meetings & $\begin{array}{l}\text { No links with } \\
\text { other associations }\end{array}$ \\
\hline $\begin{array}{l}\text { LETS } 06 \\
\text { (rural) }\end{array}$ & $\begin{array}{l}\text { Female/ Member } \\
\text { of management } \\
\text { team (founder) }\end{array}$ & 35 & 8 & $50[40-75]$ & $\begin{array}{l}\text { Variable ages. } \\
\text { Youngest aged } 23 .\end{array}$ & $\begin{array}{l}\text { Business card } \\
\text { website (stage } 1)\end{array}$ & $\begin{array}{l}\text { Bimonthly meetings } \\
+ \text { Occasional } \\
\text { knowledge-exchange } \\
\text { workshops }\end{array}$ & $\begin{array}{l}\text { No links with } \\
\text { other associations }\end{array}$ \\
\hline $\begin{array}{l}\text { LETS } 07 \\
\text { (suburban) }\end{array}$ & $\begin{array}{l}\text { Female/ Member } \\
\text { of management } \\
\text { team }\end{array}$ & 28 & 7 & $30[15-50]$ & $\begin{array}{l}\text { Variable ages. } \\
\text { Youngest aged } 30 .\end{array}$ & $\begin{array}{l}\text { Exchanges } \\
\text { coordinated using } \\
\text { the internet (stage } \\
\text { 3) } \\
+ \text { Facebook }\end{array}$ & $\begin{array}{l}\text { Monthly meetings } \\
+ \text { Occasional } \\
\text { knowledge-exchange } \\
\text { workshops }\end{array}$ & $\begin{array}{l}\text { No links with } \\
\text { other associations }\end{array}$ \\
\hline
\end{tabular}




\begin{tabular}{|c|c|c|c|c|c|c|c|c|}
\hline $\begin{array}{l}\text { LETS } 08 \\
\text { (suburban) }\end{array}$ & $\begin{array}{l}\text { Male/ Member of } \\
\text { management team }\end{array}$ & 39 & 8 & $50[40-80]$ & $\begin{array}{l}\text { Aged between } 50 \\
\text { and } 70 . \text { Majority } \\
\text { female. }\end{array}$ & $\begin{array}{l}\text { No website (stage } \\
0 \text { ) }\end{array}$ & $\begin{array}{l}\text { Monthly meetings } \\
+ \text { Regular knowledge- } \\
\text { exchange workshops }\end{array}$ & $\begin{array}{l}\text { No links with } \\
\text { other associations }\end{array}$ \\
\hline $\begin{array}{l}\text { LETS } 09 \\
\text { (urban) }\end{array}$ & $\begin{array}{l}\text { Male/ Member of } \\
\text { management team }\end{array}$ & 60 & 6 & $150[120-150]$ & $\begin{array}{l}\text { Majority female } \\
\text { and over } 50 .\end{array}$ & $\begin{array}{l}\text { Exchanges } \\
\text { coordinated using } \\
\text { the internet (stage } \\
\text { 3) }\end{array}$ & $\begin{array}{l}\text { Monthly meetings } \\
+ \text { Occasional } \\
\text { knowledge-exchange } \\
\text { workshops }\end{array}$ & $\begin{array}{l}\text { Partnerships with } \\
\text { other associations } \\
\text { (joint actions) }\end{array}$ \\
\hline $\begin{array}{l}\text { LETS } 10 \\
\text { (urban) }\end{array}$ & $\begin{array}{l}\text { Male/ Member of } \\
\text { management team } \\
\text { (founder) }\end{array}$ & 41 & 8 & $60[50-70]$ & Majority retired. & $\begin{array}{l}\text { Business card } \\
\text { website (stage } 1)\end{array}$ & $\begin{array}{l}\text { Monthly meetings } \\
\text { + Regular knowledge- } \\
\text { exchange workshops } \\
\text { + Themed talks }\end{array}$ & $\begin{array}{l}\text { No links } \\
+ \text { Conflict with } \\
\text { some local } \\
\text { associations over } \\
\text { the scope of } \\
\text { action }\end{array}$ \\
\hline $\begin{array}{l}\text { LETS } 11 \\
\text { (rural) }\end{array}$ & $\begin{array}{l}\text { Female/ Member } \\
\text { of management } \\
\text { team }\end{array}$ & 35 & 3 & $40[40-60]$ & $\begin{array}{l}\text { Majority retired and } \\
\text { over } 60 .\end{array}$ & $\begin{array}{l}\text { Exchanges partly } \\
\text { coordinated using } \\
\text { the internet (stage } \\
\text { 2) } \\
+ \text { Facebook }\end{array}$ & $\begin{array}{l}\text { Monthly meetings } \\
+ \text { Regular knowledge- } \\
\text { exchange workshops }\end{array}$ & $\begin{array}{l}\text { Partnerships with } \\
\text { other associations } \\
\text { (joint actions, } \\
\text { shared local } \\
\text { currency project) }\end{array}$ \\
\hline $\begin{array}{l}\text { LETS } 12 \\
\text { (rural) }\end{array}$ & $\begin{array}{l}\text { Female/ Member } \\
\text { of management } \\
\text { team }\end{array}$ & 34 & 10 & $40[20-40]$ & $\begin{array}{l}\text { Majority female } \\
\text { and over } 60 . \\
\text { Socially diverse. }\end{array}$ & $\begin{array}{l}\text { No website (stage } \\
0) \\
+ \text { Facebook } \\
+ \text { Twitter }\end{array}$ & $\begin{array}{l}\text { Monthly meetings } \\
+ \text { Regular knowledge- } \\
\text { exchange workshops }\end{array}$ & $\begin{array}{l}\text { Links with other } \\
\text { local associations } \\
\text { (information } \\
\text { passed on) }\end{array}$ \\
\hline $\begin{array}{l}\text { LETS } 13 \\
\text { (suburban) }\end{array}$ & $\begin{array}{l}\text { Male/ Member of } \\
\text { management team }\end{array}$ & 44 & 6 & $70[50-80]$ & $\begin{array}{l}\text { Aged between } 30 \\
\text { and } 93 \text { with } \\
\text { majority between } \\
45 \text { and } 75 . \text { Socially } \\
\text { diverse. }\end{array}$ & $\begin{array}{l}\text { Business card } \\
\text { website (stage 1) } \\
+ \text { Facebook }\end{array}$ & $\begin{array}{l}\text { Monthly meetings } \\
\text { + Regular knowledge- } \\
\text { exchange workshops } \\
\text { + Many regular events } \\
\text { (repair café, etc.) } \\
+ \text { A shared garden } \\
\end{array}$ & $\begin{array}{l}\text { Links with other } \\
\text { local associations } \\
\text { (information } \\
\text { passed on) }\end{array}$ \\
\hline $\begin{array}{l}\text { LETS } 14 \\
\text { (urban) }\end{array}$ & $\begin{array}{l}\text { Female/ Member } \\
\text { of management } \\
\text { team }\end{array}$ & 75 & 22 & $50[50-100]$ & $\begin{array}{l}\text { Aged } 45 \text { and } \\
\text { upwards (average } \\
\text { age }+/-60-65) \text {. }\end{array}$ & $\begin{array}{l}\text { Exchanges } \\
\text { coordinated using } \\
\text { the internet (stage } \\
\text { 3) }\end{array}$ & Monthly meetings & $\begin{array}{l}\text { No links with } \\
\text { other associations }\end{array}$ \\
\hline $\begin{array}{l}\text { LETS } 15 \\
\text { (suburban) }\end{array}$ & $\begin{array}{l}\text { Female/ Member } \\
\text { of management } \\
\text { team }\end{array}$ & 43 & 6 & 20 [10-40] & $\begin{array}{l}\text { Retired and } \\
\text { unemployed people. }\end{array}$ & $\begin{array}{l}\text { Exchanges partly } \\
\text { coordinated using } \\
\text { the internet (stage } \\
\text { 2) }\end{array}$ & Monthly meetings & $\begin{array}{l}\text { No links with } \\
\text { other associations }\end{array}$ \\
\hline $\begin{array}{l}\text { LETS } 16 \\
\text { (suburban) }\end{array}$ & $\begin{array}{l}\text { Male/ Member of } \\
\text { management team } \\
\text { (founder) }\end{array}$ & 36 & 7 & 55 [15-60] & $\begin{array}{l}\text { Majority retired } \\
\text { females. }\end{array}$ & $\begin{array}{l}\text { Exchanges } \\
\text { coordinated using }\end{array}$ & $\begin{array}{l}\text { Monthly meetings } \\
+ \text { Regular knowledge- } \\
\text { exchange workshops }\end{array}$ & $\begin{array}{l}\text { Links with other } \\
\text { local associations }\end{array}$ \\
\hline
\end{tabular}




\begin{tabular}{|c|c|c|c|c|c|c|c|c|}
\hline & & & & & & $\begin{array}{l}\text { the internet (stage } \\
3 \text { ) } \\
+ \text { Facebook }\end{array}$ & & $\begin{array}{l}\text { (information } \\
\text { passed on) }\end{array}$ \\
\hline $\begin{array}{l}\text { LETS } 17 \\
\text { (rural) }\end{array}$ & $\begin{array}{l}\text { Male/ Member of } \\
\text { management team }\end{array}$ & 32 & 21 & $70[30-70]$ & $\begin{array}{l}\text { Majority aged } \\
\text { between } 45 \text { and } 55 . \\
\text { Socially diverse. } \\
\end{array}$ & $\begin{array}{l}\text { No website (stage } \\
0 \text { ) }\end{array}$ & Monthly meetings & $\begin{array}{l}\text { Partnerships with } \\
\text { other associations } \\
\text { (joint actions) }\end{array}$ \\
\hline $\begin{array}{l}\text { LETS } 18 \\
\text { (suburban) }\end{array}$ & $\begin{array}{l}\text { Male/ Member of } \\
\text { management team }\end{array}$ & 68 & 9 & 70 [50-90] & $\begin{array}{l}\text { Average age around } \\
60-65 .\end{array}$ & $\begin{array}{l}\text { Business card } \\
\text { website (stage 1) } \\
+ \text { Facebook }\end{array}$ & $\begin{array}{l}\text { Monthly meetings } \\
\text { + Regular knowledge- } \\
\text { exchange workshops }\end{array}$ & $\begin{array}{l}\text { Partnerships with } \\
\text { other associations } \\
\text { (joint actions, } \\
\text { shared local } \\
\text { currency project) }\end{array}$ \\
\hline $\begin{array}{l}\text { LETS } 19 \\
\text { (rural) }\end{array}$ & $\begin{array}{l}\text { Male/ Member of } \\
\text { management team }\end{array}$ & 52 & 5 & 30 [25-45] & $\begin{array}{l}\text { Majority female } \\
\text { and over } 60 .\end{array}$ & $\begin{array}{l}\text { Total } \\
\text { dematerialisation of } \\
\text { exchanges (stage 4) }\end{array}$ & Monthly meetings & $\begin{array}{l}\text { Partnerships with } \\
\text { other associations } \\
\text { (joint actions) }\end{array}$ \\
\hline $\begin{array}{l}\text { LETS } 20 \\
\text { (suburban) }\end{array}$ & $\begin{array}{l}\text { Female/ Member } \\
\text { of management } \\
\text { team }\end{array}$ & 34 & 17 & 100 [90-100] & $\begin{array}{l}75 \% \text { retirees with } \\
\text { an average age of } \\
64 .\end{array}$ & $\begin{array}{l}\text { Total } \\
\text { dematerialisation of } \\
\text { exchanges (stage 4) }\end{array}$ & $\begin{array}{l}\text { Monthly meetings } \\
+ \text { Regular knowledge- } \\
\text { exchange workshops } \\
+ \text { Occasional talks }\end{array}$ & $\begin{array}{l}\text { No links with } \\
\text { other associations }\end{array}$ \\
\hline $\begin{array}{l}\text { LETS } 21 \\
\text { (rural) }\end{array}$ & $\begin{array}{l}\text { Male/ Member of } \\
\text { management team } \\
\text { (founder) }\end{array}$ & 28 & 12 & $20[20-30]$ & $\begin{array}{l}\text { Average age around } \\
40-50 .\end{array}$ & $\begin{array}{l}\text { Business card } \\
\text { website (stage } 1)\end{array}$ & Monthly meetings & $\begin{array}{l}\text { No links with } \\
\text { other associations }\end{array}$ \\
\hline $\begin{array}{l}\text { LETS } 22 \\
\text { (rural) }\end{array}$ & $\begin{array}{l}\text { Female/ Member } \\
\text { of management } \\
\text { team (founder) }\end{array}$ & 65 & 1 & $30[15-30]$ & $\begin{array}{l}\text { Majority aged } \\
\text { between } 50 \text { and } 60 .\end{array}$ & $\begin{array}{l}\text { Exchanges } \\
\text { coordinated using } \\
\text { the internet (stage } \\
\text { 3) }\end{array}$ & $\begin{array}{l}\text { Monthly meetings } \\
+ \text { Schedule of regular } \\
\text { knowledge-exchange } \\
\text { workshops } \\
+ \text { Repair Café project }\end{array}$ & $\begin{array}{l}\text { No links with } \\
\text { other associations }\end{array}$ \\
\hline $\begin{array}{l}\text { LETS } 23 \\
\text { (urban) }\end{array}$ & $\begin{array}{l}\text { Female/ Member } \\
\text { of management } \\
\text { team (founder) }\end{array}$ & 83 & 2 & 95 [70-95] & $\begin{array}{l}\text { Majority female } \\
\text { aged between } 35 \\
\text { and } 45 \text {. }\end{array}$ & $\begin{array}{l}\text { Exchanges } \\
\text { coordinated using } \\
\text { the internet (stage } \\
3 \text { ) } \\
+ \text { Facebook }\end{array}$ & $\begin{array}{l}\text { Monthly meetings } \\
\text { + Regular knowledge- } \\
\text { exchange workshops }\end{array}$ & $\begin{array}{l}\text { Partnerships with } \\
\text { other associations } \\
\text { (joint actions, } \\
\text { shared local } \\
\text { currency project) }\end{array}$ \\
\hline
\end{tabular}

